УДК: 339.9: $338.46(1-925.8 / .9)$

DOI 10.30970/vir.2018.45.0.9436

\title{
THE USE OF RESORT DESTINATIONS AND EVENT TOURISM RESOURCES OF LVIV REGION TO STIMULATE THE DEVELOPMENT OF TOURISM IN CARPATHIAN REGION
}

\author{
Marta Barna, Mariia Topornytska \\ Lviv Trade and Economics University, \\ 10, Tugan-Baranovskoho Str., Lviv, Ukraine, 79008, tel. 275-65-50, \\ e-mail:martabarna@ukr.net,Topornytska Maria@i.ua
}

\author{
Marta Malska \\ Ivan Franko National University of Lviv, \\ 1, Universytetska Str., Lviv, Ukraine, 79000, \\ e-mail:malskym@ukr.net
}

\begin{abstract}
With the help of comparative, mathematical-statistical and analytical methods of research, an attempt was made to outline the territorial organization and socio-geographical principles of tourism development through symbiosis of recreational resources and event tourism resources of Lviv region. The Carpathian region has a great potential for the development of various types of tourism. It is characterized by the presence of unique tourist-recreational, natural resources and a rich ecosystem. By the number of mineral water deposits, their diversity and available reserves, Ukraine occupies one of the leading places in Europe. In Lviv region, almost all types of mineral waters are found. In point of fact, these powerful natural remedies are increasingly used in numerous resorts and sanatoria. Lviv region is also rich in ski resorts, which will satisfy any and all tourist's taste, thanks to various slopes, trails, developed infrastructure and beautiful winter sceneries. Despite the rich natural potential of recreation, it is also organically complemented by numerous heritage sites of history, culture, architecture, which is also attractive for Ukrainian and foreign tourists, both for recreation and for health, spiritual and intellectual enrichment. In addition to the historical and cultural resource, the region is rich in event attractions: festyny (feasts), festivals, celebrations, celebrations of religious holidays in their traditions, ethnofestivals and many other events. In order to strengthen the competitiveness of each locality in the region, it is necessary to evaluate the potential market of tourist services, to develop and start implementing a program of active promotion of local tourism products.
\end{abstract}

Key words: tourism; resort deportations; event tourism resources; Lviv region; tourist potential.

It was repeatedly noted that modern tourism plays an important role in the formation of the economy of any country. Tourist activity has become one of the leading, highly profitable branches of the economy. Taking into account the Lviv region, its favorable geographical location, rich natural, resource, historical and cultural potential, we can mention about the potential and the development of culturalcognitive, scientific-educational, religious, health-improving, ecological, business and other types of tourism.

(C) Barna Marta, Malska Marta, Topornytska Mariia, 2018 
Today, natural, historical and cultural resources take the leading place in the structure of tourist potential of Lviv region.

Regarding the recreational potential of the region, the reserves of medical and mineral waters, medical muds, ozokerite, water and forest resources take the leading place. Resorts are developed based on certain types of mineral waters, among which Truskavets is a balneological resort with one of the best developed infrastructures. Truskavets is known far beyond Ukraine due to the diversity of mineral waters. The most famous of these is the miracle water - «Naftusia». This European-style resort that is dynamically developing and being built. In Truskavets, there is a large number of sanatoriums, boarding houses, hotels, and private estates. Skhidnytsa is balneological resort, on mountain passes which has 38 mineral water springs. In Skhidnytsia excellent conditions are created for recreation and complex treatment of many ailments using diverse means, among which - mineral waters for internal and external use, ozokerite therapy, therapeutic gymnastics and special healing Carpathian air. Mineral waters of Skhidnytsia have no analogues in Europe, combining the healing qualities of water of such famous resorts as Truskavets, Kislovodsk (Russia) and Borjomi (Georgia). Morshyn is one of the most famous gastroenterological resorts in Ukraine thanks to its unique mineral water sources, good geographical location, convenient transport links and environmentally friendly environment. One of the main therapeutic factors of Morshyn is mineral springs, as well as peat mud and ozokerite. Morshyn resort area is located separately from the residential part, almost all sanatoria are located in a beautiful park zone that smoothly changes into the forest. Mineral water of Morshyn, due to anti-inflammatory, choleretic, diuretic and mitigating effects, helps purify the body, eliminate radionuclides, and increase immunity. The same as in Shklo, Velykyi Lubin.

Large deposits of ozokerite, one of the world's largest reserves of high-quality ozokerite (earth, mountain wax), is located within Boryslav $10 \mathrm{~km}$ from Skhidnytsia. This is a very rare rock. In Skhidnytsia, ozokerite is used at full capacity for treatment different ailments. In practice, medicines are used on the basis of ozokerite and other petroleum products (paraffin, vaseline) - ozokerafin, ozokeralin, ozoparafine, ozokerafine napkin, medical ozokerite. It was observed that the therapeutic effect of «Naftusia» significantly reinforced even after a single application with ozokerite. The properties of ozokerite in medicine and technology in for humans are still studied.

Therapeutic peat muds of Nemyriv, Velykyi Lubin, Morshyn deposits and Shklo deposit also belong to medical balneological resources of Lviv region.

We can see that in Lviv region, one of the oldest types of recreation is the sanatorium and resort business, which in the market conditions of today undergoes qualitative structural changes - there are health resorts of the highest European standard. For example, in Truskavets, one of the oldest health resorts in Europe, the medical centers «Rixos-Prykarpattia», «Med Palas», sanatorium «Shale Hraal» are the institutions that offer the latest technology of domestic health resort and physiotherapy, and which effectively combines with the best world's achievements in medicine. In Skhidnytsia - DiAnna the medical and health center. 
Ukrainian part of the Carpathian region, unlike other tourist regions of Ukraine due to terrain features and rich ecosystem can meet consumer demand for leisure and recreation all year round, without special signs of seasonality, guaranteeing an excellent treatment both in summer and in winter. Apart from the fact that the season is not an obstacle, the positive feature is that sanatoria consider both adults and children. So, relax in the resort is ideal for family holidays [8].

According to the Lviv city council, a wide network of spa facilities is established and successfully function in the region, which includes 56 resorts and recreation facilities where 111 thousand people were treated in 2016 [9].

In addition to healing and health resorts, the climatic conditions of the Carpathians are comfortable for the organization of winter recreational activities, in particular for active rest at the ski resorts of the Lviv region: Slavske, Plavie (Plai), Oriavchyk, Zveniv, Volosianka, Tysovets, Village Rozluch.

These popular ski centers are known for their trails of various difficulty. Tourist infrastructure of ski resorts has a wide variety of services for tourists and visitors of Lviv region: SPA-centers, ski instructor services, snow tubing and sledging, ski slopes and mogul lovers and many others. The settlement of Tysovets was once known as the center of winter sports of international importance. The snow lies for a long time here. In Tysovets, trails for cross-country skiing, biathlon, mogul, freestyle, snowboarding, snow tubing is laid. Here you can ride sleds, there are ski jumps. Near the village of Rozluch, in one of the recreation centers, trail for the beginners is laid. There are mineral water sources in the village, which are similar to the waters of Naftusia and Borjomi. At the rest base, theatrical performances are held during Christmas holidays. Among the entertainment, available to the guests of the base, in addition to skis, you can mention sleds, skating rink, and billiards.

But, experts more and more point out that in practice, when only one tourist resource is used in one of the seasons - summer or winter, it reduces the resource efficiency of tourism. Such limitation and seasonality of the tourist industry reduces its profitability, and sometimes makes it unprofitable in the periods of the off-season [6].

The seasonal demand for recreational resources, in terms of stability of the business by tourism enterprises, is a significant factor in reducing the business activity. Resorts settlements in the Carpathians each time passively expect a «high» season, for example, skiing. Natural anomalies such as insufficient height of snow cover in the mountains, low temperature or a large amount of precipitation in the summer further complicate the situation and increase the losses which ultimately leads to the collapse of the activities of many participants in the tourist market. Therefore, an important task is to find ways to diversify the use of regional resources in the offseason, in order to attract mass tourist flows into these settlements both in the autumn and spring and throughout the summer [2]. One of the priority types of positioning for this group of settlements is the holding of various seasonal attractions in the Carpathians in the off-season.

Tourism activity, directed by several directions, will revitalize the economic activity of local communities, increase employment of the population, attract local 
entrepreneurs into the sphere of tourist services and in general will «work» on the tourist image of the settlements covered by it.

In each of these resort towns of Lviv region, certain events are recorded: historical, cultural, artistic, and others.

The development of event tourism in small historical towns and villages of Lviv region, the expansion of the range of services for tourists who come to the city of Lviv or travel to Lviv region, will help to distribute the tourist flows rationally, as it now targets the regional center - Lviv.

Depending on the tourist positioning in the world it is accepted to distinguish between the following types of city tourist centers: centers of cultural and cognitive tourism, centers of business tourism, centers of event tourism (including festival tourism centers), resort towns, pilgrimage centers, recreation centers and entertainment centers [3]. At the same time, the vast majority of modern cities are developing in several segments of tourist services and position itself as multifunctional tourism centers.

Infrastructure of centers for cultural and educational tourism, which combines not only individual architectural structures, religious objects, museums, theaters, galleries and exhibition halls, but also complexes of buildings, structures, streets and parks, is at the same time a resource for the deployment of a wide range of cultural and mass events, for example, festival tourism. Such an organic combination of tangible and intangible components of the tourist potential creates a unique atmosphere and tourist diversity of cities - centers of mass tourism.

The health resorts, since their foundation, have focused on narrow therapeutic and specific features, nowadays, besides the basic courses of treatment and rehabilitation, they began to offer general health programs, turning into multifunctional healthrecreation and entertainment centers, designed for a wide range of consumers. By creating conditions for attracting new categories of tourists by diversifying their stay programs, conducting a series of ethno-artistic, cultural and sporting events, they quite successfully position themselves as centers of festival and show-tourism.

Holding national, regional and local festivals and event-tourist activities also significantly affect the stabilization of mass tourism during the «low» season and offseason in areas - centers of mining, religious and ethnographic tourism.

Considerable historical and ethno-cultural potential coupled with growing interest in the history of the region and cultural heritage make it possible to develop ethnofestival tourism in most cities and villages of Lviv region. Maintaining in a proper condition historical and cultural objects, attracting private capital to create the appropriate infrastructure, holding festivals and local festyns, fairs, folk events of the regional level will contribute to increasing the tourist attractiveness of the settlements of Lviv region and will serve as a prerequisite for the targeted economic and cultural positioning of them as centers of ethno-tourism.

In order to strengthen the competitiveness of each locality in the region, it is necessary to evaluate the potential market of tourist services, to develop and start implementing a program for the active promotion of local tourism products, to 
coordinate the principles of cooperation and mechanisms of support of local selfgovernment bodies which are the organizers of local cultural and mass initiatives.

The resort areas of the Lviv region are very rich in various events. For example, various festivals are held here, such as: Lemko culture festival «To you I go, my native land» (Lemkivska Vatra) in village Nahirne in Sambir district, Festival of Medieval Culture and Folk Art «Tu Stan!» in the village of Urych in Skoliv district, Art Festival-Contest «Karpatiia» in Truskavets, International Carpathian Festival of Regional Culture in Truskavets, Festival-Contest «The Springs of Morshyn» in Morshyn, Bruno Schulz International Festival in Drohobych, International Music Festival «Slavske-Rock», International Festival of Culture of Ethnic Groups and Peoples of Carpathian Euroregion «Karpatiia» in the village of Lavriv in Staryi Sambir district, Festival of patriotic song (to the anniversary of the creation of the Ukrainian Main Liberation Council) in Sprynia in Sambir district, Festival of bard song and singing poetry «Beskydy» in the village of Verkhnie Syniovydne in Skole district, Ethno-festival «Kulchytsi-fest» in the village of Kulchytsi in Sambir district, Regional Festival of Folk Song and Music «Echo of Boiky Land» in town of Turka, World Boiky Festyny Ethno-cultural (once every five years) in Turka and the village of Yavora in Turka district, World congress of boiky (once every four years) in Turka. Festival of air balloons, festival «Summer in Skhidnytsia», Mystical festival «Molfar ROCK».

In addition to the healing, therapeutic resources, the resort towns have a rich historical and cultural heritage: Museum of Omelian Stotskyi, St. Nicholas Church, Park of Panteleimon the Healer in Skhidnytsia; villas: «Hopliana», «Hrazhyna», «Siriush», «Sofia» and other architectural monuments in Morshyn, as well as «Resort Park»; Museum of History of Truskavets, Art Museum of Mykhailo Bilas, Eparchy Museum and others in Truskavets and many others.

The main advantages of the event (including festival) tourism is its versatility and high profitability, therefore the leading tourist firms and hotel companies of Lviv take an active part in its organization. It is important to emphasize that stability and regularity of festival events, price stability, the possibility of using economic incentives are important for tour firms. Only under such conditions, the tourism business will be able to actively participate in the celebration of city events and festivals.

The village of Nahirne in Sambir district has become more popular among tourists exclusively thanks to the successive (every September) holding of ethno-festival «Lemkivska Vatra». Although Festyny in Nahirne has not yet acquired the status of a prominent ethnic festival of historic Lemky region, festival «Lemkivska Vatra» remain the biggest Lemky international feast in the neighboring Poland (48\% of the Lemky region is now located in Poland, $41 \%$ - in Slovakia and only $11 \%$ - in Ukraine). Indigenous inhabitants of the region started this festival in the village of Nahirne, to unite for cooperation, preservation of its linguistic dialect, culture, restoration of the monuments of Lemky history and material culture. Similar festivals take place in Polish Zhdynia and Mikhalovo and Slovak Svydnyk. Due to long-term of ethno-positioning, the Polish town of Zhdynia is now a recognized center of the 
ethnographic land of Lemkivshchyna. Lemky from all over the world gather here on «Lemkivska Vatra» to meet friends and relatives, to visit their native land, to bow to the graves of the great-grandparents. Tourists are welcomed in rural cottages, where they not only receive standard rural tourism services, but are directly involved in Lemko culture and folklore. A similar model of tourist attraction and service is being implemented by the community of the Ukrainian village of Nahirne. With the growing popularity of Lemkivska Vatra in Sambir district and the proper customization of hospitality infrastructure, Nahirne may «grow» into the popular center of international ethno-festival tourism in the coming years.

Summing up, we will emphasize the necessity to urgently develop and implement domestic and international campaigns for promotion of ethno-cultural heritage and festival-tourist possibilities of settlements of Lviv region to stimulate and support the organization of national and international ethno-artistic, cultural and entertaining events (festivals, artistic planners, exhibitions of traditional crafts, etc.), to introduce and promote tourist programs and products (such as «For coffee to Lviv», «Festival of medieval culture» «Tu Stan!», «Great Koliada» in Lviv, etc.) as well as to support the efforts of local authorities in this field.

So, in order for tourism to really develop successfully and compete not only on the domestic but also on the international market, a complex of measures should be developed that will enable the formation of a highly efficient tourist complex that meets world standards and meets the needs of the international consumer. The natural, cultural and cognitive resources of the Carpathian region need to be successfully, skillfully and, as much as possible, beneficial, which will contribute to the revitalization of the tourist movement, and those, in turn, will contribute to increasing the interest in the local culture and stimulate the promotion of the cultural and ethnographic potential of this territory.

Further clear positioning of the settlements of the region in the market of ethnofestival tourism, the formation and promotion of ethno-festival brands, will attract the development of cultural and tourist potential as separate settlements, as well as the region as a whole, will activate the formation of the international image of Lviv as a tourist center, accelerate the development of tourism and recreational infrastructure, eventually, will «work» to improve the international image of Ukraine.

\section{REFERENCES}

1. Beidyk O. O. Methodology and methods of analysis of recreational and tourist resources of Ukraine. - Kyiv, 2004.

2. Bukharova $O$. V. Ethno-tourism in the Carpathian recreation region: the search for optimal forms / O. V. Bukharova // Turystyka w Euroregionie Karpackim. Perspektywy rozwoju. - Rzeszow, 2007. P. 48-52.

3. Dzhaman V. O. Regional systems of resettlement: demographic aspects. - Chernivtsi : Ruta, 2003. $-392 \mathrm{p}$.

4. Diadechko L. P. Economy of tourism business. - Kyiv, 2007.

5. Panderetskyi O. V. Territorial organization of industrial tourism of the Carpathian social and geographical region and the main directions of its improvement (section 4).

6. Holloway J. K. Tourist business: transl. from 7th Eng. ed. / J. K. Halloway, N. Taylor. - Kyiv : Znannia, 2007. - $798 \mathrm{p}$. 
Marta Barna, Marta Malska, Mariia Topornytska

7. Yakovenko I. M. Theoretical and methodological foundations of recreational nature use (sociogeographical research); National Academy of Sciences of Ukraine; Institute of Geography. - Kyiv, 2004.

8. http://www.niss.gov.ua/articles/1178/.

9. http://www.oblrada.lviv.ua.

Стаття надійшла до редколегії 10.06.2018

Прийнята до друку 01.09.2018

\title{
ВИКОРИСТАННЯ КУРОРТНИХ ДЕСТИНАЦЙ ТА ПОДІЕВИХ ТУРИСТИЧНИХ РЕСУРСІВ ЛЬВІВЩИНИ ДЛЯ СТИМУЛЮВАННЯ РОЗВИТКУ ТУРИЗМУ КАРПАТСЬКОГО РЕГІОНУ
}

\author{
Марта Барна, Марія Топорницька \\ Львівський торговельно-економічний університет, \\ вул. Туган-Барановського, 10, м. Львів, Украӥна, 79008, тел. (032) 275-65-50, \\ e-mai:martabarna@ukr.net,TopornytskaMaria@i.ua
}

\section{Марта Мальська}

Львівський національний університет імені Івана Франка, вул. Університетська 1, м. Львів, Украӥна,79000, e-mail:malskym@ukr.net

Iз застосуванням порівняльного, математико-статистичного та аналітичного методів дослідження здійснено спробу окреслити територіальну організацію та суспільно-географічні засади розвитку туризму через симбіоз рекреаційних ресурсів та подієвих туристичних ресурсів Львівської області. Карпатський регіон має потужній потенціал для розвитку різних видів туризму. Він характеризуються наявністю унікальних туристично-рекреаційних, природних ресурсів та багатою екосистемою. За кількістю родовищ мінеральних вод, їх різноманітністю та наявними запасами Україна посідає одне із провідних місць у Європі. На Львівщині виявлені майже усі типи мінеральних вод. Власне ці могутні природні лікувальні засоби знаходять все більше застосування на численних курортах та санаторіях. Львівщина також багата i на гірськолижні курорти, які задовільнять будь-якого i на будь-який смак туриста, завдяки різноманітними схилами, трасами, розвиненою інфраструктурою i прекрасними зимовими пейзажами. Незважаючи на багатий природний потенціал рекреації органічно доповнюється $\mathrm{i}$ численним спадком пам'яток історії, культури, архітектури, що $є$ теж привабливим для українських та іноземних туристів, як для відпочинку так i оздоровлення, духовного та інтелектуального збагачення. Окрім історико-культурного ресурсу, регіон багатий на подієві атракції: фестини, фестивалі, урочистості, святкування релігійних свят у їх традиціях, етнофестивалі та багато інших подій. Для зміцнення конкурентоспроможності кожного населеного пункту регіону необхідно реально оцінити потенційний ринок турпослуг поселення, розробити та розпочати реалізувати програму активного просування локального турпродукту.

Ключові слова: туризм; курортні дестинації; подієві туристичні ресурси; Львівський регіон; туристичний потенціал. 